to all workers who have to deal with blue books and other official papers. It is. so arranged that with a minimum of delay it is possible to find what statistics are available on any given subject. The degree of analysis of the figures, the dates and places to which they apply, and the price of the volumes containing them can be readily found. There is also given a list of the publications of various Government departments arranged under the departments.

\section{National Radium Commission}

THE now National Radium Commission has been elected and consists of the following members : the Earl of Donoughmore (Chairman), Sir Cuthbert Wallace (Vice-Chairman), Dr. T. Carnwath, Dr. T. Ferguson, Dr. Rupert Hallam, Dr. G. W. C. Kaye (appointed by the Department of Scientific and Industrial Research), Prof. J. C. G. Ledingham (appointed by the Medical Research Council), Mr. J. J. M. Shaw, Mr. G. F. Stebbing, Prof. Beckwith Whitehouse, Prof. James Young; Joint Secretaries, Dr. G. W. C. Kaye and Mr. G. F. Stebbing; Office Secretary, Miss K. Griffiths. The Commission will meet as heretofore at 5 Adelphi Terrace, Strand, W.C.2.

\section{The Sky in October}

ALc the naked-eye planets are now absent from the evening sky except Saturn, which is conspicuous and fairly well placed for evening observation : the stellar magnitude will decline from $+0 \cdot 8^{\mathrm{m}}$ to $+1 \cdot 0^{\mathrm{m}}$ during the month, but the planet is rather far south, as also was Jupiter this summer, Saturn's declination being $-11^{\circ} 50^{\prime}$ on October 15. Venus is now an early morning object, and will attain its greatest brilliance on October 15. Mars and Jupiter are both near the sun. Uranus will be in opposition on October 27, and there will be a conjunetion of Neptune with Venus on October 25 , Venus being $2^{\circ} 6^{\prime} \mathrm{S}$. The minor planet Vesta is now in the evening sky, not far from Saturn. Intensive observations on the minor planets have been started at Greenwich, in pursuit of a plan for making greater use of these small objects for determining the position of the equinox. They just show a disc in the 8-in. transit telescope, but resemble a star far more closely than does Venus (and a fortiori the sun), so that the minor planets are very suitable objects to observe in order to tie up the right ascensions and declinations of the solar system with the fundamental right ascensions and declinations of the stars. The principle involved is that the observation of a planet from the earth is equal and opposite to an observation of the earth from the planet, so that besides observing the planet's orbit we observe our own, and find the point where our orbit cuts the equator, that is, the equinox.

\section{Announcements}

THE opening lecture of a series on "Scientific Progress" organised by the Sir Halley Stewart Trust will be given by Sir James Jeans in the Memorial Hall, Farringdon Street, London, on Tuesday, October 22. The subject will be the new world picture as seen by the modern physicist. Other contributors to the series are Sir William Bragg, Prof. E. V. Appleton, Prof. E. Mellanby, Prof. J. B. S. Haldane, and Prof. Julian Huxley. Free reserved tickets are obtainable from the Trust, 32 Gordon Square, W.C.1.

THE Robert Koch medal has recently been awarded by the City of Berlin to Dr. Ferdinand Sauerbruch, professor of surgery in Berlin, the Emil Fischer medal to Dr. Adolf Butenandt, professor of organic chemistry and technology in Danzig, and the Liebig medal to Dr. Walther Roth, professor of physical chemistry at Brunswick.

A LECTURE on the work of the expedition of the Egypt Exploration Society (2 Hinde Street, W.1) to Tell el-Amarna 1934-5 will be given by the field director, Mr. J. D. S. Pendlebury, on Monday, October 7, at 8.30 p.m. in the rooms of the Royal Society, Burlington House, Piccadilly, London, W.1.

The sixtieth series of free lectures at the Horniman Museum, Forest Hill, S.E.3, will begin on October 12 at 3.30, when Mr. E. C. Stuart Baker will lecture on "Wild Men and Wild Beasts in India". Further information can be obtained from the Curator of the Museum.

IT has come to the notice of the National Institute of Agricultural Botany that a Danish 're-selected' stock of Resistance Oats is being offered on the English market. The Institute desires to state that no seed of this variety was distributed prior to the autumn of 1934 .

THE Electrodepositors' Technical Society, which has been responsible for the organisation of the Electrodeposition Exhibition in the Science Museum at South Kensington, will hold a Soirée in the Museum on Oetober 18. The Exhibition will be open from 6.15 until 10.30 p.m., during which time a lecture will be given by Mr. S. Field on progress in electrodeposition and a film will be shown dealing with commercial applications of electrodeposits. Admission to the Museum will be by ticket. The Society welcomes applications from members of kindred societies and institutions and from others interested in the theory or practice or applications of electro-deposition. Applications should be made immediately to the assistant hon. secretary, Capt. A. I. Wynne-Williams, 12A, Raleigh House, Larkhall Estate, London, S.W.8.

Applications are invited for the following appointments, on or before the dates mentioned:

An assistant in the London Museum, St. James's, S.W.1-The Keeper (Oct. 28).

A secretary for the Society for Cultural Relations with the U.S.S.R., 21 Bloomsbury Square, London, W.C.I-The Chairman.

A woman lecturer in geography and mathematics in St. Hild's College, Durham-.The Principal. 